\title{
Rethinking the World
}

GREAT POWER STRATEGIES

AND INTERNATIONAL ORDER

\author{
JeFFREY W. LEgRo
}

Cornell University Press

ITHACA AND LONDON 


\section{Copyright $@ 2005$ by Cornell University}

All rights reserved. Except for brief quotations in a review, this book, or parts thereof, must not be reproduced in any form without permission in writing from the publisher. For information, address Cornell University Press, Sage House, 512 East State Street, Ithaca, New York 14850.

First published 2005 by Cornell University Press

Printed in the United States of America

Library of Congress Cataloging-in-Publication Data

Legro, Jeffrey

Rethinking the world : great power strategies and international order / Jeffrey W. Legro.

p. cm. - (Cornell studies in security affairs)

Includes bibliographical references and index.

ISBN-13: 978-0-8014-4272-8 (cloth : alk. paper)

ISBN-10: 0-8014-4272-9 (cloth : alk. paper)

1. International organization. 2. International relations. I. Title.

II. Series.

JZ1308.L44 2005

327.1'01-dc22

2005008834

Cornell University Press strives to use environmentally responsible suppliers and materials to the fullest extent possible in the publishing of its books. Such materials include vegetable-based, low-VOC inks and acid-free papers that are recycled, totally chlorine-free, or partly composed of nonwood fibers. For further information, visit our website at www.cornellpress.cornell.edu.

Cloth printing $\quad \begin{array}{llllllllll}10 & 9 & 8 & 7 & 6 & 5 & 4 & 3 & 2 & 1\end{array}$ 
Rethinking the World 
A volume in the series

Cornell Studies in Security Affairs edited by Robert J. Art, Robert Jervis, and Stephen M. Walt A full list of titles in the series appears at the end of the book. 
To the Reverend Janet Hatfield Legro 
